\title{
Skin Burn by Termal Mattress - A Therapeutic Approach
}

\author{
Rochelle Gorczak, Marilia Avila Valandro, Isabella Michels Carvalho \& Ana Carolina Coelho
}

\begin{abstract}
Background: Burns are caused by a direct or indirect action of heat on an organism, compromising the functional integrity of the skin. Hypothermia is a common intercurrence in animals during the transoperative period; thermal mattresses are used to maintain the animal's body temperature, but inappropriate use can cause the patient's skin to burn. In humans, burns are quite common; however, in veterinary medicine, they are infrequent. The aim of this study was to describe a case of accidental burn in a canine caused by a thermal mattress, emphasizing wound treatment and analgesia used.

Case: A 12-year-old male canine without defined breed weighing $15 \mathrm{~kg}$ underwent an emergency exploratory laparotomy due to rupture of a spleen mass and presented with intercurrence hypothermia during the anesthesia procedure, which was controlled using a thermal mattress. Ten days after the surgical procedure, he developed a skin lesion with erythema, suffusion, and necrosis, evolving skin displacement along the entire back with a lot of pain which was possibly caused by the use of a thermal mattress in the transoperative procedure. The intuited analgesic treatment involved the use of numerous and different drugs, including Methadone $(0.3 \mathrm{mg} / \mathrm{kg}$, QID, SC), Dipyrone $(25 \mathrm{mg} / \mathrm{kg}$, TID, IV), and Ketamine $(0.5 \mathrm{mg} / \mathrm{kg}$, TID, SC) (during hospitalization), as well as Tramadol (4 mg/kg, TID, PO) and Dipyrone ( $25 \mathrm{mg} / \mathrm{kg}, \mathrm{TID}, \mathrm{PO}$ ) after medical release as support therapy. For the wound treatment, calcium alginate was initially used daily and subsequently changed for daily application of dermisana oil. The patient followed up weekly for approximately two months for wound monitoring as well as adjustments to the drug therapy. The would almost completely healed, but the patient showed a significant worsening in the general clinical condition correlated with the neoplasm that he had, and the owner and clinical staff of the veterinary hospital opted for euthanasia.

Discussion: Hypothermia should be avoided as much as possible during anesthesia, as the body's temperature is very important in homeostasis, in addition to being able to change the pharmacokinetics and pharmacodynamics of some drugs. The use of a thermal mattress to avoid hypothermia during the intraoperative period is a common and useful tool in veterinary routine, but should be used with caution and constant monitoring of the animal under general anesthesia to avoid skin burns which are not immediately noted. When diagnosed, the treatment should aim for wound healing and provide analgesia. Different pharmacological approaches can be used for this purpose, including topical therapies with different products that provide wound healing and regard to analgesia can be used for association of non-steroidal antiinflammatory drugs such as meloxicam, opioids like morphine and tramadol, and N-Methyl-D-aspartate (NMDA) blockers like ketamine for analgesia. Burn treatment is difficult but can have a favorable prognosis. In the present report, the conservative wound management using sodium alginate and dermisana oil almost completely cured the wound, and the canine responded positively to the analgesic protocol instituted with the association of different drugs. It is still important to highlight the attendance and commitment of the owner in the proposed treatment, as euthanasia, in this case, was due to the comorbidity presented by the patient.
\end{abstract}

Keywords: analgesia, general anesthesia, wound, hypothermia, intraoperative complications. 


\section{INTRODUCTION}

The body is covered by skin, which is responsible for thermoregulation and protection against external factors and is composed of the epidermis, dermis, and hypodermis [7]. Burns are the result of a direct or indirect action of heat on an organism, compromising the functional integrity action of the skin and reaching the epidermis, epidermis with a partial part of the dermis, or even deep tissues $[1,2,14,15]$. The most frequent causes are fire, boiling water, or heated objects [9].

Hypothermia is a relatively common intercurrence during surgery, and a thermal mattress is often used to maintain the body temperature during a surgical procedure. It should be used with caution because prolonged contact can cause thermal trauma $[21,22]$ and skin burns [11]. This injury is ischemic due to a lack of oxygenation of the tissues, making it difficult for the growth of the capillaries [2] and leading to shock [1]; when it compromises more than $15 \%-20 \%$ of the body surface, it can generate systemic changes, requiring supportive therapy $[14,21]$. Basically, the therapy for burns is based on skin treatment [1] beyond constant analgesia [21] because they can cause intense pain, and the patient must be monitored daily to establish an adequate protocol $[13,14]$.

Burns are generally a public health problem, and in Brazil, it is one of the principal causes of death in humans [15]; however, there are few reports in veterinary cases $[1,14,21]$.

This study aimed to report a case of accidental skin burn of a canine by thermal mattress, describing the wound treatment for the burn and the analgesia used.

\section{CASE}

A 12-year-old male canine without a defined breed weighing $15 \mathrm{~kg}$ was admitted due to a tumor and organ rupture, as well as a liver biopsy (later the histopathologic report confirmed hemangiosarcoma in both). The previous hematological exams were within normal limits expected for the species. The animal was diagnosed with asymptomatic mitral valve endocarditis, and the results of the pre-anesthetic physical exam were as follows: heart rate (HR) $180 \mathrm{bpm}$, respiratory rate (RR) 24 breaths/min, PAS $120 \mathrm{mmHg}$, glucose $110 \mathrm{mg} / \mathrm{dL}$, hypo-colored mucus, CPT <2”, temperature $38.8^{\circ} \mathrm{C}$, and classified as ASA III according to the American Society of Anesthesiology.

The patient received methadone ${ }^{1}\left[\right.$ Mytedom $^{\mathrm{TM}}$ - $0.4 \mathrm{mg} / \mathrm{kg}$, IM] was induced to general anesthesia with propofol ${ }^{1}$ [Propovan ${ }^{\mathrm{TM}}-5 \mathrm{mg} / \mathrm{kg}$, IV] and was subsequently intubated and kept on a circular system with oxygen at $100 \%$ and inhalatory anesthesia with isoflurane $^{1}$ (Isoforine ${ }^{\mathrm{TM}}$ ). The transoperative duration was $80 \mathrm{~min}$, and $30 \mathrm{~min}$ into the procedure, the patient's temperature began dropping, so a thermal mattress was turned on to maintain the body temperature. We constantly monitored the multiparametric measurements of HR, RR, systolic blood pressure, MAD, diastolic blood pressure, and esophageal temperature (Table 1). In this period, the patient received fentany ${ }^{1}{ }^{\text {[Fenta- }}$ nest $^{\mathrm{TM}}-2.5 \mathrm{mg} / \mathrm{kg}$, IV] and ephedrine sulfate ${ }^{1}$ [Efedrin $^{\mathrm{TM}}-0.1 \mathrm{mg} / \mathrm{kg}$, IV]. At the end of the procedure, the patient was extubated, receiving Dipyrone ${ }^{2}\left[\mathrm{D}-500^{\mathrm{TM}}\right.$ - $25 \mathrm{mg} / \mathrm{kg}$ ], and meloxicam ${ }^{3}$ [Maxicam ${ }^{\mathrm{TM}} 0.2 \%$ $0.05 \mathrm{mg} / \mathrm{kg}$ ], both IV. After $36 \mathrm{~h}$, he was discharged.

After 10 days, the animal returned to the hospital presenting a coetaneous lesion in the right thoracic dorsal region with erythema, suffusion, and necrosis, and the surgical stitches were removed. After this, the patient received chemotherapy. After more than 10 days, he returned presenting necrotic lesions with skin displacement along all dorsal regions (Figure 1A and 1B)

Table 1. Trans-anesthetic monitoring with a 10-minute interval between measurements.

\begin{tabular}{ccccccccc}
\hline & T10 & T20 (F) & T30 & T40 & T50 (E) & T60 & T70 & T80 \\
\hline HR (bpm) & 140 & 142 & 160 & 180 & 180 & 180 & 190 & 190 \\
FR (mpm) & 12 & 12 & 20 & 20 & 30 & 32 & 36 & 40 \\
PAS & 110 & 90 & 98 & 140 & 80 & 86 & 94 & 96 \\
PAM & 80 & 76 & 80 & 98 & 62 & 70 & 78 & 80 \\
PAD & 66 & 58 & 66 & 70 & 52 & 62 & 66 & 66 \\
TR $\left({ }^{\circ} \mathrm{C}\right)$ & 37.8 & 37.5 & 37.3 & 37.4 & 37.7 & 37.8 & 38.0 & 38.1 \\
\hline
\end{tabular}

F- fentanyl $2.5 \mathrm{mcg} / \mathrm{kg}$, IV; E- ephedrine $0.1 \mathrm{mg} / \mathrm{kg}$, IV. 


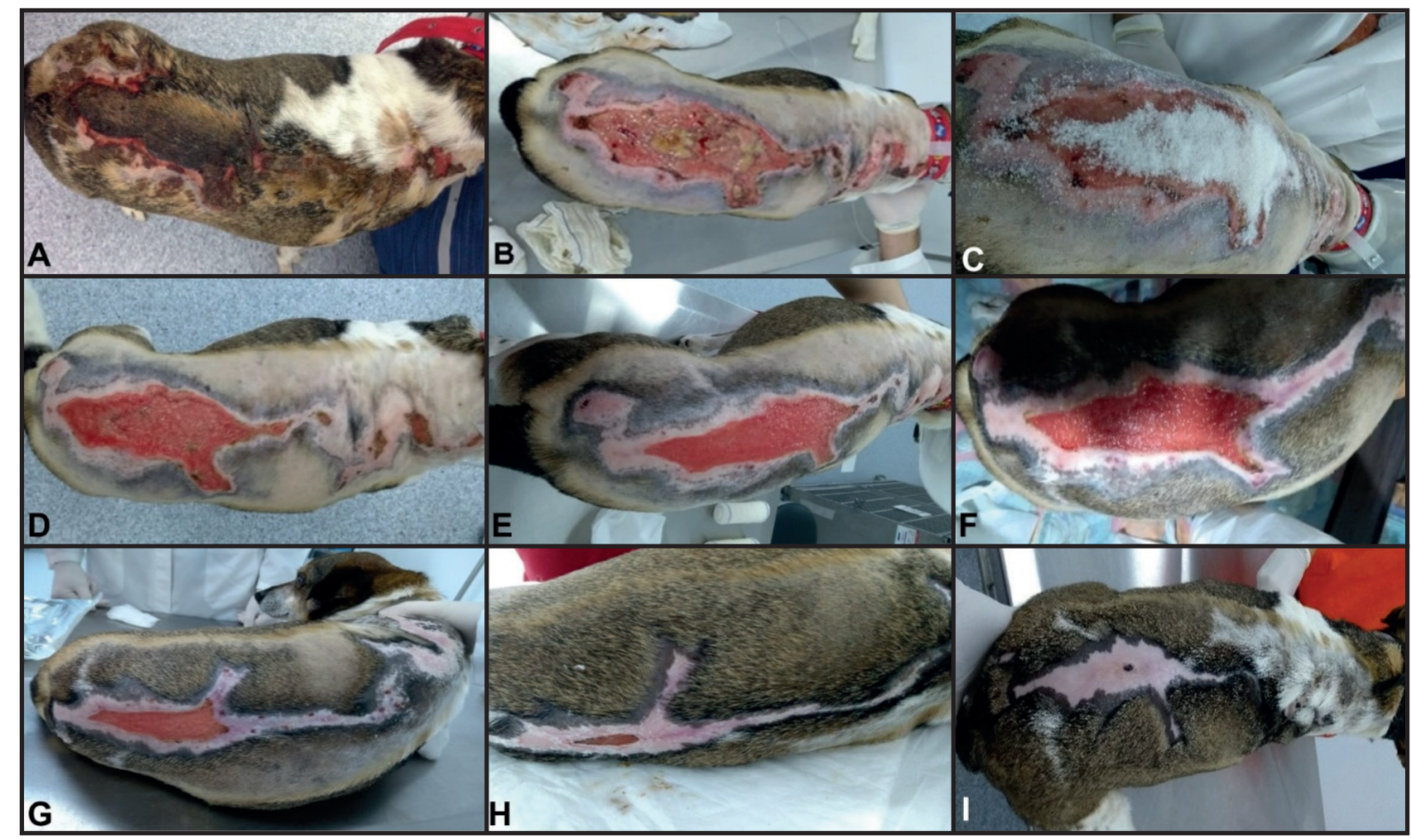

Figure 1. Evolution of wound healing by burn. Injury to the patient's back, before (A) and after skin removal, showing the extent of the lesion and the presence of necrotic tissue (B). Debridement of the lesion with crystal sugar (C). Wound without the presence of necrotic tissue, with good healing evolution, on the day of the patient's medical discharge (D). Wound appearance 7 days (E), 14 days (F), 21 days (G), 28 days (H) and 40 days (I) after the start of treatment.

and a lot of local pain, possibly caused by a burn from the thermal mattress during surgery. Then, the wound was cleaned with a $0.9 \%{ }^{4}$ arm physiological solution (Fisiológico $0.9 \%$ TM), debridement with crystal sugar (Figure 1C), and silver sulfadiazine ${ }^{5}$ (Sulfadiazina de Prata $^{\mathrm{TM}}$ ) with the first dressing. At the next dressing change, this was substituted for calcium alginate ${ }^{6}[\mathrm{Ca}-$ sex Algicare ${ }^{\mathrm{TM}}$ - SID]. We started analgesic therapy with methadone $^{1}$ [Mytedom $^{\mathrm{TM}}-0.3 \mathrm{mg} / \mathrm{kg}$, QID, SC]; dipyrone $^{2}$ [D-500 $\left.{ }^{\mathrm{TM}}-25 \mathrm{mg} / \mathrm{Kg}, \mathrm{TID}, \mathrm{IV}\right]$; and ketamine ${ }^{7}$ [Cetamin ${ }^{\mathrm{TM}}-0.5 \mathrm{mg} / \mathrm{Kg}$, TID, SC], as well as antibiotic therapy with cephalothin ${ }^{8}$ [Keflin $^{\mathrm{TM}}-30 \mathrm{mg} / \mathrm{kg}$, TID, IV]. After 4 days, the wound showed good ciatrization without necrosis (Figure 1D), and the patient was discharged. We maintained analgesic treatment with tramadol $^{9}$ [Cloridrato de Tramadol ${ }^{\mathrm{TM}}$ - $4 \mathrm{mg} / \mathrm{kg}$, TID], and dypirone ${ }^{9}$ [Dipirona Sódica ${ }^{\mathrm{TM}}{ }_{-} 25 \mathrm{mg} / \mathrm{kg}$, TID, for 10 days], as well as antibiotic therapy with cephalexin ${ }^{9}$ [Cefalexina $\left.^{\mathrm{TM}}-30 \mathrm{mg} / \mathrm{kg}, \mathrm{BID}\right]$, and Omeprazole ${ }^{10}$ [Gaviz V VM - $1 \mathrm{mg} / \mathrm{kg}$, SID, for 20 days]; all drugs were taken orally and the wound was dressed daily with calcium alginate $^{6}$ (Casex Algicare $\left.{ }^{\mathrm{TM}}\right)$.

The patient continued to return weekly for wound monitoring as well as adjustments to the medication therapy. At the first return (Figure 1E), the wound had great evolution, and the dressing with calcium alginate $^{6}$ (Casex Algicare $^{\mathrm{TM}}$ ) was changed to daily application of dermisana oil ${ }^{11}$ (Dersani ${ }^{\mathrm{TM}}$ ). In the second week (Figure 1F), the analgesic therapy was suspended and the antibiotic therapy and oil application were maintained. At the third (Figure 1G) and fourth (Figure 1H) weeks, only the oil application was maintained. About 60 days after the surgical procedure and 40 days after the beginning of the treatment for the burn, the patient returned with quite prostate and vomiting, and consequently was not receiving the medication. The physical examination showed lateral decubitus and little responsiveness with $39.8{ }^{\circ} \mathrm{C}$ temperature, jaundice mucous, dehydration at $6 \%$, HR $100 \mathrm{bpm}$, and RR 40 breaths/min, but the wound was completely healed (Figure 1I). Because the patient's clinical condition had significantly worsened due to the neoplasm and other comorbidities that he had, the clinical staff and the owner opted for euthanasia.

\section{DISCUSSION}

The use of a thermal mattress is routine in veterinarian practices, principally during surgical 
procedures, as one of the principal transanesthetic intercurrences is hypothermia. When using this equipment to avoid losing heat in patients $[19,20]$, the patient should be constantly monitored, as constant heat can cause thermal burns [11]. The patient in question was submitted to an exploratory laparotomy procedure and in order to avoid hypothermia, he constantly received heat from a thermal mattress, which maintained the ideal transoperative temperature, but the degree of heat on the animal's body likely was not verified appropriately.

Anesthesia is directly connected to postoperative hypothermia, and in the first three hours post-anesthesia, dogs present with a drop in body temperature of approximately $3^{\circ} \mathrm{C}$. Furthermore, metabolism and heat production are reduced with physiological thermoregulation changed by the anesthetic agents [19]. In this reported case, the anesthetic procedure lasted $80 \mathrm{~min}$, and a thermal mattress was turned on after $30 \mathrm{~min}$ to reduce heat loss and maintain body temperature.

General anesthesia causes an important drop in body temperature which is time dependent. Anesthetic induction promotes a fall of $20 \%$ in metabolic heat production, similar to inhibition of physiological thermoregulation response, normally stimulated by hypothermia [19]. During general anesthesia, patients depress the central nervous system thermoregulatory center. Thus, the equilibrium between production and temperature loss is affected, which could result in different techniques of heat during the procedure, often externally. This external heat can cause skin burns in animals, without necessarily causing a general change in body temperature [20]. In the present case, the patient remained within the ideal species temperature, reaching a maximum of $38.1^{\circ} \mathrm{C}$, not characterizing hyperthermia.

Body temperature is of utmost importance to homeostasis equilibrium. Hypothermia should be avoided as much as possible during anesthesia, and the association of anesthetic with temperature loss can lead to changes in the cardiovascular system, blood coagulation, immune system, and hormonal levels. Furthermore, this condition can induce changes in the pharmacokinetics and pharmacodynamics of some drugs normally used in this practice. Propofol and fentanyl increase the plasma concentration to $30 \%$ and $50 \%$, respectively, when body temperature is $3^{\circ} \mathrm{C}$ less than normal. In addition, the partition coefficient of inhaled anesthetics and their solubility is high. Moreover, CAM can reduce about $5 \%$ in animals that show hypothermia
[19]. In this patient, serum assessment was not performed to ensure that the drugs changed the plasma and we did not monitor the partition coefficient or CAM, but the patient remained under inhalation anesthesia with low flow throughout the procedure.

The severity of a burn injury can vary according to the techniques used, being partly superficial or totally, according to the depth of the burn, $[1,17]$. In thermal burns, the skin can change in $48-72 \mathrm{~h}$, and consequently hair starts to fall off or can be easily removed, principally in deeper burns [14]. Furthermore, the patient can present with erythema, transient desquamation, and burned hair [21]. In addition, accidents caused by chemical burns are described as injuries with erythema, edema, and crusts. Dunlop et al. [4] conducted one of the first surveys of cases with thermal burns in dogs that received transoperative heat using gloves with hot water. Coetaneous injury was observed from 6 to 12 days after the procedure. In the present case, the patient returned for an exam about 10 days after the procedure and presented with a coetaneous lesion in the thoracic dorsal region, with erythema, suffusion, and necrosis.

In the described case, the wound was initially debrided with crystal sugar and dressed with silver sulfadiazine, as recommended by the literature. Sugar has antibacterial effects and can modulate the inflammatory reaction through hyperosmolarity; its use is recommended for wounds to accelerate healing $[3,16]$. The topical effect of the wound treatment also serves to reduce local edema and periregional vascular congestion, improve oxygenation and irrigation, degrade fibrin tissue, stimulate macrophages, and mature tissue granulation [6]. Many techniques using different substances are available with respect to aiding healing, increasing speed and efficacy, and decreasing treatment time and owner costs [18]. Calcium alginate is used in human medicine for infected wounds, and it is associated with systemic antimicrobial therapy, which is indicated as an exudation wound. It is derived from a seaweed with great exudate absorption capacity, hemostatic and bacteriostatic action, and replacement of daily dressing [16]. The use of alginate in this report was of great value, as it reduced the exudates and necrotic tissue, in addition to aiding in rapid epithelialization of the wound.

Between the many options for burn treatment, we recommend using enzyme ointments and essential 
fatty acids (AGE), which are composed of linoleum acid, caprilic acid, vitamins A and E, and soy lecithin. These compounds are precursors of pharmacologically active substances involved in the process of cell division and epidermal differentiation, in addition to changing leukocytes and speeding up the process of tissue granulation [5]. They were also used in the present report, where we opted for therapy with dermisana oil, a compound based on AGE, and demonstrated an excellent healing process using it.

Analgesic therapies are essential for burn cases, and the pain for the patient can be classified as severe or torturous [8]. Every patient should be evaluated individually; this analgesic support can be transdermal, topical, or systemic [12]. Pasini \& Soares [13] used an analgesic patient protocol for a fire burn with tramadol [4 mg/kg, TID], ketamine [1 mg/kg, TID], dipyrone $[25 \mathrm{mg} / \mathrm{kg}$, TID], and methadone $[0.4 \mathrm{mg} / \mathrm{kg}$, QID], which was considered an adequate therapeutic support due to remission of pain signals and apparent lack of adverse effects. This was similar to that in the highlighted patient, where the protocol involved similar drugs, varying slightly on doses administered.

Furthermore, ketamine $[0.5 \mathrm{mg} / \mathrm{kg}$ followed by CI 2 to $10 \mathrm{mg} / \mathrm{kg} / \mathrm{min}$ ] was used for simultaneous analgesia by blocking N-methyl-D-aspartate. Opioids should be associated with a drug synergism, and could be weak (tramadol) or moderate to strong (morphine, methadone, or fentanyl), depending on the pain that the patient shows [12], as was the case in this report, where ketamine was administered at doses associated with opioids. The use of tramadol associated with NSAID carprofen orally was previously described as providing pain relief to a dog with chemical burns, similar to the report dog, where tramadol was used in association with dipyrone. If the animal is admitted and starts showing systemic changes, indicating pain, in addition to ketamine CI, fentanyl tape, or fentanyl $\mathrm{CI}$ as analgesic support, one could also include association with dexmedetomidine CI, and if necessary, an intervention by general anesthesia to minimize the animal's suffering [8]. However, in the present reported $\operatorname{dog}$, this kind of intervention was not necessary.

Beyond the wound and pain, the cardiorespiratory and renal functions must be constantly monitored, even days after the burn [14]. Vasoconstriction caused by burns can cause renal failure in patients with shock [21]. The dog in this report was under observation for some days and started returning periodically, but did not show clinical or laboratorial relevant changes. Burns are hypermetabolic, with high temperature, catabolism, need for oxygen, tachypneia, and tachycardia [12], signs that were identified on the patient and established after the beginning of treatment.

A hypersensitivity reaction to a drug, called pharmacodermia, should be considered a different diagnosis for burns, due to the similarity of the tegument injury, which manifests as a coetaneous reaction commonly associated with systemic signs [10]. This hypothesis was discarded when we observed the injury extension and the affected areas in the patient, knowing that the animal did not receive medications in that region. Furthermore, the drugs previously administered, to the best of our knowledge, do not have studies indicating association cases of pharmacodermia. Another differential that must be evaluated is dorsal thermal necrosis caused by sunburn, principally if the patient is short-haired and dark colored [17], which was not considered in this case because the patient was not short-haired or exposed to the sun.

The use of a thermal mattress to avoid hypothermia during the transanesthetic period is a useful tool; however, caution must be exercised and the animal should be constantly monitored under general anesthesia to avoid skin burns. Such burns are not typically immediately noted; when identified, the treatment should aim for the wound healing process and provide analgesia to the animal. Wound treatment is difficult, both for the professional and owner's commitment, in addition to its expensive costs, but if correctly realized, the patient has a favorable prognosis. In the present report, the conservative management of the wound almost completely healed it. In addition, the patient had a positive response to the analgesic protocol. It is important to emphasize the owner's attendance and commitment during the treatment. In this case, the patient was submitted to euthanasia because of systemic complications and associated pathologies. However, it is important to emphasize that there are few reports on burns by thermal mattresses, as it can be considered a medical error and most professionals prefer not to expose themselves.

\section{MANUFACTURERS}

${ }^{1}$ Cristália Produtos Químicos e Farmacêuticos Ltda. São Paulo, SP, Brazil.

${ }^{2}$ Zoetis Indústria de Produtos Veterinários Ltda. Campinas, SP, Brazil. 
${ }^{3}$ Ourofino Saúde Animal Ltda. Cravinhos, SP, Brazil. ${ }^{4}$ JP Indústria Farmacêutica S.A. Ribeirão Preto, SP, Brazil.

${ }^{5}$ Prati, Donaduzzi \& Cia Ltda. Toledo, PR, Brazil.

${ }^{6}$ Casex Indústria de Plásticos e Produtos Médicos Hospitalares Ltda.

Curitiba, PR, Brazil.

${ }^{7}$ Syntec do Brasil Ltda. Cotia, SP, Brazil.

${ }^{8}$ Antibióticos do Brasil Ltda. Cosmópolis, SP, Brazil.
${ }^{9}$ EMS S/A. Hortolândia, SP, Brazil.

${ }^{10}$ Union Agener Animal Health. Augusta, GA, USA.

${ }^{11}$ Laboratório Daudt Oliveira Ltda. Rio de Janeiro, RJ, Brazil.

Declaration of interest. The authors report no conflicts of interest. The authors alone are responsible for the content and writing of the paper.

\section{REFERENCES}

1 Albernaz V.G.P., Ferreira A.A. \& Castro J.L.C. 2015. Queimaduras térmicas em cães e gatos. Veterinária e Zootecnia. 22(3): 322-334.

2 Alves L.B., Eurides D., Baungarten L.B., Busnardo C.A., Silva L.A.F., Oliveira B.J.N.A. \& Souza L.A. 2011. Chemical burns by fipronil in a dog's breed rottweiler. Revista Nosso Clínico. 14(80): 48-52.

3 Cavazana W.C., Simões M.L.P.B., Yoshii S.O., Amado C.A.B. \& Cuman R.K.N. 2009. Açúcar (sacarose) e triglicerídeos de cadeia média com ácidos graxos essenciais no tratamento de feridas cutâneas: estudo experimental em ratos. Anais Brasileiros de Dermatologia. 84(3):229-36.

4 Dunlop C.I., Daunt D.A. \& Haskins S. 1989. Thermal Burns in Four Dogs during Anesthesia. Veterinary Surgery. 18(3): 242-246.

5 Ferreira E., Lucas R., Rossi L.A. \& Andrade D. 2003. Curativo do paciente queimado: uma revisão de literatura. Revista da Escola de Enfermagem da USP. 37(1): 44-51.

6 Guirro E.C. B.P., Puntel F.C., Bebber B.A., Thomas L.D., Luiz R.M. \& Viott A.M. 2015. Efeito do açúcar em diferentes formulações na cicatrização por segunda intenção em ratos Wistar. Veterinária em Foco. 13(1): 2-8.

7 Junqueira L. C. \& Carneiro J. 2013. Histologia Básica: Texto e Atlas. 12.ed. Rio de Janeiro: Guanabara Koogan, pp.354-359.

8 Kawalilak L.T., Fransson B.A. \& Alessio T.L. 2017. Management of a facial partial thickness chemical burn in a dog caused by bleach. Journal of Veterinary Emergency and Critical Care. 27(2): 224-231.

9 Leão C.E.G. 1999. Queimaduras. In: Fonseca F.P. \& Rocha P.R.S. (Eds). Cirurgia Ambulatorial. 3.ed. Rio de Janeiro: Guanabara Koogan, pp.122-128.

10 Lima D.A.S.D., Quessada A.M., Lima W.C., Silva F.A.N., Rodrigues N.M., Rodrigues M.C. \& Sousa J.M. 2012. Reação farmacodérmica em cão: relato de caso. MEDVEP Dermato. 2(4): 224-227.

11 Mazzaferro E.M. 2012. Choque térmico. In: Rabelo R. (Ed). Emergências de Pequenos Animais. Rio de Janeiro: Elsevier, pp.303-309.

12 McKune C.M., Murrell J.C., Nolan A.M., White K.L. \& Wright B.D. 2015. Nociception and Pain. In: Grimm K.A., Lamont L.A., Tranquilli W.J., Greene S.A. \& Robertson S.A. (Eds). Lumb \& Jones' Veterinary Anesthesia and Analgesia. 5th edn. Ames: Wiley Blackwel, pp.584-617.

13 Pasini J.S. \& Soares A.V. 2017. Analgesia em canino com queimadura extensa. Revista Nosso Clínico. 20(119): 26-32.

14 Pead M.J. \& Langley-Hobbs S.J. 2013. Manejo agudo de lesões ortopédicas e de tecidos moles externos. In: King L.G. \& Boag A. (Eds). Manual BSAVA de Emergência e Medicina Intensiva em Cães e Gatos. 2.ed. São Paulo: MedVet, pp.324-358.

15 Ramos A.F., Porto O.S. \& Guerra A.D.L. 2019. Diagnósticos e intervenções de enfermagem a um paciente com queimadura por choque elétrico: Estudo de caso. Revista Científica da Escola Estadual de Saúde Pública Goiás "Cândido Santiago". 5(2): 76-87.

16 Rocha J.A., Miranda M.J. \& Andrade M.J. 2006. Abordagem terapêutica das úlceras de pressão - Intervenções baseadas na evidência. Acta Médica Portuguesa. 19: 29-38.

17 Schwartz S.L., Schick A.E., Lewis T.P. \& Loeffler D. 2018. Dorsal thermal necrosis in dogs: a retrospective analysis of 16 cases in the southwestern USA (2009-2016). Veterinary Dermatology. 29(2): 139-e55.

18 Simas S.M. 2010. O tratamento de feridas cutâneas em cães e gatos. 112p. Porto Alegre, RS. Monografia (Conclusão de curso). Faculdade de Veterinária, Universidade Federal do Rio Grande do Sul.

19 Soares G.C.L., Cardoso C.G. \& Junior E.M. 2015. Causas e consequências da hipotermia: a importância da monitoração da temperatura no perioperatório. Revista de Investigação Veterinária. 14(6): 1-7. 
R. Gorczak, M.A.Valandro, I.M. Carvalho \& A.C. Coelho. 2021. Skin Burn by Termal Mattress - A Therapeutic Approach. Acta Scientiae Veterinariae. 49(Suppl 1): 594.

20 Tan C., Govendir M., Zaki S., Miyake Y., Packiarajah P. \& Malik R. 2004. Evaluation of four warming procedures to minimise heat loss induced by anaesthesia and surgery in dogs. Australian Veterinary Journal. 82(1-2): 65-68.

21 Tello L.H. 2012. Queimaduras. In: Rabelo R. (Ed). Emergências de Pequenos Animais. Rio de Janeiro: Elsevier, pp.529-535.

22 Wilson D.V. \& Shih C.A. 2015. Anesthetic Emergencies and Resuscitation. In. Grimm K.A., Lamont L.A., Tranquilli W.J., Greene S.A. \& Robertson S.A. (Eds). Lumb \& Jones' Veterinary Anesthesia and Analgesia. 5th edn. Ames: Wiley Blackwel, pp.114-129. 